\title{
SEXTING AS A RISKY BEHAVIOR AND THE PARENTAL MONITORING FROM THE PERSPECTIVE OF ADOLESCENTS
}

\section{[SEXTING AKO FORMA RIZIKOVEHO SPRAVANIA A MIERA RODICOVSKEJ KONTROLY Z POHLADU DOSPIEVAJUCICH]}

\author{
Tomas Turzak - Viera Kurincova - Katarina Holla
}

doi: 10.18355/PG.2020.9.2.3

\begin{abstract}
Sexting as a risky behavior of adolescents is determined by the family environment, by the family structure and by the quality of mutual relations in the family. The aim of the study was to explore the relation between the frequency of self and peer sexting and parental monitoring from the perspective of adolescents. The research involved 790 respondents (adolescents aged 12-18 years) who were administered the modified questionnaire "Cyberbullying and sexting" (modified by K. Holla). The results suggest that adolescents who do not talk to their parents about online risky behaviour are more likely to report that they engage in peersexting. There is a relationship between parental monitoring of adolescents' online activity and sending and receiving erotic and sexual material from their friends.
\end{abstract}

Key words

family environment, parents, adolescents, risky behaviour, sexting, virtual world, parental monitoring

\begin{abstract}
Abstrakt
Rodinné prostredie, kvalita vzájomných vzt’ahov v rodine a štruktúra rodiny sú jednými z určujúcich faktorov, ktoré podmieňujú výskyt sextingu ako jednej z foriem rizikového správania detí a dospievajúcich. Hlavným ciel'om štúdie bolo preskúmat' vzt'ah medzi frekvenciou odosielania self a peer-sextu a mierou rodičovskej kontroly $\mathrm{z}$ pohl'adu dospievajúcich. Výskumu sa zúčastnilo 790 respondentov (dospievajúcich vo veku 12 - 18 rokov). Výsledky boli získané administráciou upraveného dotazníka „Kyberšikana a sexting" (modifikovaný K. Hollou). Klúčovým zistením realizovaného výskumu je, že dospievajúci, ktorí sa nerozprávajú s rodičmi o online nástrahách a rizikách, častejšie priznávajú peer-sexting. Posielanie erotických a sexuálnych materiálov svojich kamarátov a spolužiakov, vrátane vyžiadania si intímnych materiálov pre vlastnú potrebu, je závislé od zástoja rodičov v online aktivitách ich dospievajúcich detí.
\end{abstract}

\section{Kl’účové slová}

rodinné prostredie, rodičia, dospievajúci, rizikové správanie, sexting, virtuálne prostredie, rodičovská kontrola 


\section{Úvod}

V odborných kruhoch sa často diskutuje o rozdieloch, ktoré existujú vo vzt’ahu kelektronickým médiám medzi príslušníkmi jednotlivých generácií (i ked', samozrejme, tieto charakteristiky nemožno generalizovat', nakol'ko vek človeka tu nie je rozhodujúcim determinantom). Kým pre generáciu súčasných detí ako tzv. „Net-generáciu“ (resp. „Mileniánov“, či „Digitálnych domorodcov“, Generáciu Y) je typické, že sa narodila do prostredia, v ktorom sú elektronické médiá jeho prirodzenou súčast'ou, generácia ich rodičov označovaná ako „Digitálni prist’ahovalci“ (generácia obdobia tzv. „Baby boom“, či „Z generácia“) si vzt’ah k moderným médiám a zručnosti s tým spojené musela postupne vytvárat'. Stáva sa, že práve deti rodičom radia, ako s digitálnou technikou pracovat' (tzv. „reverzná mediácia“). Často sú to i tieto momenty, ktoré tvoria kontext výchovy v rodine a významne ovplyvňujú vzájomné vzt'ahy rodičov a ich detí, ich komunikáciu, hodnoty, pohl'ady na dianie okolo seba a pod.

Problémy, ktoré riešia vo výchove súčasní rodičia detí a adolescentov sa v mnohom podobajú (odrážajú vývinové charakteristiky dospievajúcich), ale svet moderných elektronických médií prináša fenomény, ktoré sú na jednej strane pozitívnym faktorom formovania mladého človeka, na strane druhej prinášajú najrozmanitejšie riziká, ktorým dospievajúci a ich rodičia musia čelit'. Do tohto rámca patrí aj skúmanie správania sa detí a dospievajúcich $\mathrm{v}$ kyberprostredí $\mathrm{v}$ súvislosti $\mathrm{s}$ ich sexualitou a možnými ohrozeniami sextingom.

Napriek tomu, že v posledných rokoch bolo publikovaných množstvo vedeckých štúdií, stále sa vynárajú otázky, ktoré nie sú adekvátne zodpovedané. Medzi výskumníkmi existuje výzva viac pozornosti venovat' skúmaniu samotných dospievajúcich, ich pohl'adom a vysvetl'ovaniu online sexuálnych aktivít, než prezentovaniu názorov dospelých - rodičov a učitel'ov. Podl'a S. J. Walker pohl'ady dospelých na začiatku 21.storočia na sexting predstavovali niečo, čo pripomínalo až „,morálnu paniku“ z takéhoto správania. Ich vnímanie situácie okolo sextingu dospievajúcich nie vždy odrážalo skutočne to, ako k problematike pristupovali samotní mladí. Môžeme konštatovat', že virtuálny svet pre tých, ktorí sú práve v štádiu objavovania a vynárania sa vlastnej sexuality, získavajú prvé skúsenosti s ňou, diskutujú na chatoch o ,tabu“ témach je napokon bezpečnejší ako reálny svet, v ktorom sa pohybujú (Subrahmanyam, K. et al., 2004). Existujú teda isté disproporcie medzi názormi dospelých a mladých. Dospelí často nesprávne nazerajú a prezentujú to, čo sa odohráva v živote dospievajúcich. Ako v tejto súvislosti S. J. Walker konštatuje, práve hlas mladých musí byt' vypočutý (2012). V tomto smere treba vysoko pozitívne hodnotit' výskumné aktivity realizované v rámci európskeho projektu Kids Online network, kde výskumníci získali množstvo dát o správaní sa detí a dospievajúcich v online prostredí z 19 krajín Európy (včítane Slovenska) a kde práve spomínaný „hlas mladých“ bol centrom výskumného zámeru (EU-Kids-Online 2020).

Autori tejto štúdie vo viacerých svojich príspevkoch vychádzajú zo všeobecne akceptovaného vysvetlenia sextingu ako konania, pri ktorom sú odosielané alebo prijímané elektronické správy (napr. cez SMS, MMS, alebo e-mail), alebo sa posiela/prijíma materiál s erotickým a sexuálnym obsahom, 
či významom (napr. nahé alebo polonahé fotografie a videá). V skupine sexterov (odosielatel'ov sextu) sa rozoznávajú typy agresívnych, nátlakových, alebo konsenzuálnych sexterov. Termín nesexteri sa využíva pre označenie tých, ktorí vedia, čo je sexting, ale v sextingu sa neangažujú. Účast' v sextingu môže byt' dobrovol'ná alebo nátlaková. Dôvody zapojenia sa do sextingu vychádzajú $\mathrm{z}$ dôvery, resp. reciprocity medzi účastníkmi, anonymity, ale i zámeru niekomu ublížit', dehonestovat' ho. Sexting vždy predstavuje riziko (aj ked' nemusí byt' bezprostredné). Pre obet' sextingu môžu mat' uvedené aktivity vel'mi vážne emocionálne, psychosomatické, či sociálne dôsledky. Ak sa zdiel'ajú materiály spadajúce do rámca sextingu medzi det'mi staršími ako 15 rokov, ale mladšími ako 18 rokov, právne môžu byt' klasifikované ako detská pornografia (bližšie in Holla, K., Iuventa, online, Holla, K. a kol., 2017, Smahel, D. a kol., 2020).

\section{Teoretický rámec skúmanej problematiky}

Domáca, ale najmä zahraničná literatúra v posledných rokoch prináša mnoho výskumných zistení o sexuálnych aktivitách v kyberpriestore a okolnostiach, ktoré vedú $\mathrm{k}$ možným ohrozeniam dospievajúcich sextingom. Je evidentné, že ide o problém, ktorý z hl'adiska výchovy nie je jednoduché zvládnút'. Má charakter multideterminujúci a jeho riešenie vyžaduje interdisciplinárny prístup. Prelína sa v n̆om okrem pedagogického aspektu nevyhnutne i aspekt psychologický, sociologický a právny. Naše pohl'ady na sexting môžeme situovat' do viacerých rovín. Sú to:

1. rovina psycho-sociálnych a biologických charakteristík dospievajúcich,

2. rovina problematického a rizikového správania dospievajúcich,

3. rovina rešpektovania digitálneho sveta (spolu s rodinou, školou a vrstovníkmi) ako sociálneho kontextu vývoja dospievajúcich, včítane utvárania ich sexuality, identity, intimity a interpersonálnych kontaktov,

4. rovina najbližšieho rodinného prostredia a vplyvov rodičovskej autority,

5. a napokon i rovina existencie hypersexualizovaného prostredia, ktoré nás v posledných rokoch obklopuje.

Tieto roviny sa nedajú oddel'ovat', neexistujú izolovane a spoločne tvoria bázu pre vysvetlenia online rizikového správania. Tento fakt zároveň komplikuje i exaktné vymedzenie podielu jednotlivých determinantov sextingu v prípade dospievajúcich.

Autori M. Veresova a R. Tomsik (2019) vymedzujú rizikové správanie ako také aktivity, pri ktorých vo všeobecnosti nie je jasný výsledok a ide o balansovanie medzi možnost’ami negatívnych dopadov (strát) a ziskov (pozitívny dopad). Medzi prejavy rizikových aktivít dospievajúcich okrem iného zarad'ujú i rizikové sexuálne správanie, čo je podložené početnou, najmä zahraničnou, literatúrou (Verešová, M., Tomsik, R., 2019, Smahel, D. a kol. 2020).

Významnými témami pre dospievajúcich $\mathrm{v}$ online priestore sú témy spojené so sexom. Internetové „chat rooms“ poskytujú pre mladých priestor 
na bezpečnú komunikáciu o tom, čo ich $\mathrm{v}$ tejto oblasti zaujíma a zároveň sú priestorom pre vytváranie sexuálnej identity dospievajúceho, ako na to poukazujú výsledky výskumov K. Subrahmanyam, P. M. Greenfield, B. Tynes (2004). Autori však upozorňujú i na možné ohrozenia a riziká, ktoré v tomto smere komunikácia na internete prináša.

V zahraničnej literatúre sa objavujú rôzne teórie, ktoré vysvetl'ujú zvýšený záujem využívania internetu a moderných médií pre sexuálne aktivity. Ako príklad možno uviest' „Triple A Engine Theory“ (Cooper, A., 1998). Teória vychádza z toho, čo internet záujemcovi v tomto smere poskytuje: l'ahkú dostupnost' kontaktu kdekol'vek (easy accessibility), cenová dostupnost', finančná nenáročnost' (affordability) and anonymitu (anonymity) účastníka. Neskôr sa objavila teória výskumníkov Hertlein \& Stevenson (2010), ktorí ju rozšíríli o d’alšie „A“, sedem „A“ (approximation, acceptability, ambiguity accommodation) - na vyjadrenie toho, čo na rozdiel od reálneho sveta môže pomôct' v intímnom živote riešit' dvojiciam svet virtuálny (bližšie in Cooper, A. et al., 2000, Jonsson, L. S., 2015, s. 18, Hertlein, K. M., - Stevenson, A., 2010). K. Young et al. vytvorili model „ACE“, založený na významoch slov v tomto kontexte ako anonymity (internet poskytuje anonymitu), convenience (aktivita prebieha v pohodlí domova) and escape (kedykol'vek možno sexting zastavit', vycúvat' z aktivity) (Griffiths, D. M., 2017), podobne je to v teórii „Triple C Engine“ (Reinhold, 2000) - net poskytuje účastníkom možnosti komunikácie (communication), spolupráce (collaboration) a budovania sociálneho života vo virtuálnom priestore (social life - construction of virtual communities) (Leiblum, S., Doring, N., 2002, In Cooper, A. ed. 2002).

Za nie menej významný považujeme tzv. Co-constructive model (vychádzajúci z Vygotského sociokultúrnej teórie), ktorý vypracovali $\mathrm{K}$. Greenfield, P. Subrahmanyam a D. Smahel (2006) a v ktorom je na základe výskumu potvrdené, že pre súčasných dospievajúcich online svet tvorí prirodzenú súčast' ich života. Spolu s rodinou, školou a vrstovníkmi patrí digitálny svet do sociálneho kontextu dospievajúceho. Treba ho považovat' za významnú základňu i pre jeho offline svet, zohráva významnú úlohu pri utváraní sexuality, identity, intimity a interpersonálnych kontaktov (Walker, S., J., 2012). Online a offline svety sú vzájomne previazané a pre mladého človeka neexistujú izolovanie. Virtuálny svet je $\mathrm{v}$ istom zmysle i tréningovým, prípravným, priestorom pre svet reálny.

Každý mladý človek je jedinečný a každý je zároveň formovaný mnohými vnútornými a vonkajšími činitel'mi, osobitostami dospievania, príslušnost'ou k pohlaviu, špecifickou kultúrou a pod. Treba ho vnímat' ako jedinca vo fáze vývinu, kde sú stavebnými či rozvojovými úlohami jeho veku utváranie identity, autonómie, intimity a sexuality a na strane druhej sú tu limity, ktoré sú spojené s biologickými, kognitívnymi a sociálnymi zmenami, ktoré ho ovplyvňujú. Fáza postupného prechodu z detstva do dospelosti je pre dospievajúceho tiež typická „konfrontáciou so súborom spoločenských a iných životných nárokov a zároveň pretrvávajúcim obmedzeným prístupom $\mathrm{k}$ osobnej autonómii, ekonomickej nezávislosti, neobmedzenej slobode či sexuálnej slobode“ (Veresova, M., Tomsik, R., 2019). 
Z psychologického hladiska ide o vel'mi zložitý proces, ktorý vnímame ako postupné dozrievanie mladého človeka v celej spleti sociálnych vzt’ahov a interakcií s prostredím, v ktorom žije. Inšpiratívna $\mathrm{v}$ tomto smere (teda i v kontexte sextingu) je aplikácia Bronfenbrennerovej bio-ekologickej teórie (2005) autormi L. S. Jonsson (2015) a J. Buren (2018). Zdôrazňuje sa tu dynamický vzt’ah medzi dospievajúcim a jeho sociálnym svetom, v ktorom sú jeho individuálne charakteristiky (biologické, kognitívne, emocionálne a behaviorálne) v interakcii s rôznymi úrovňami sociálneho priestoru (bližšie in Jonsson, L. S., 2015, s. 29 - 31). Autorka L. S. Jonsson na základe viacerých výskumov konštatuje, že existuje vzt'ah medzi nižším záujmom a starostlivost’ou rodiča o diet’a a možným rizikovým online sexuálnym správaním (sextingom), resp. takéto správanie a zlé vzt’ahy rodič dospievajúci (prípadne $\mathrm{v}$ situácii menej súdržnej rodiny). K podobným výsledkom dospela i J. M. Norman, ktorá konštatuje, že u dospievajúcich, ktorí sú viac naviazaní na rodinu a rodičov ako na vrstovníkov je menej pravdepodobné, že sa budú angažovat' v sextingu. Rovnako komunikácia rodič -dospievajúci je jedna $\mathrm{z}$ najvýznamnejších ciest ako rodičia $\mathrm{v}$ tomto smere môžu ovplyvňovat' svoje deti (Norman, J. M., 2017).

Podobné výskumy zamerané na vplyv rôznych faktorov rodinného prostredia na sexuálne správanie mladého človeka realizovali i autori D. Wight, L. Williamson a M. Henderson (2006). Porovnávajúc i výsledky iných výskumov dospeli k tomu, že tento vztah (i ked' často diskutabilný) je evidentný, ale sú nevyhnutné d’alšie výskumy a precizácia ich metodologických postupov (bližšie in Wight, D., Williamson, L., Henderson, M., 2006, s. 474 - 492).

$\mathrm{V}$ dnešnom svete nie je jednoduché byt' rodičom a pripravit' sa na túto rolu dospelého človeka. Rodičovstvo je vel'mi zodpovednou úlohou, pri ktorej plnení sa dospelý nevyhnutne musí menit'. Dobrý rodič citlivo sleduje to, ako jeho diet’a rastie a vyvíja sa a spolu s tým reflektuje jeho potreby. Jedna z prvých autoriek, ktorá poukázala na to, ako sa rodičia postupne menia s dospievaním vlastných detí bola autorka E. Galinska. Zdôraznila, že rodič postupne potrebuje nové a nové zručnosti a mení svoje roly vo vzt’ahu $\mathrm{k}$ diet'at'u tak, aby dokázal reagovat' na jeho vekové charakteristiky. Autorka podrobne analyzovala 6 štádií rodičovstva, z nich najmä 4. štádium (The Interpretive Stage) - ked' diet’a vstupuje do školy a je školákom a 5. štádium (The Interdependent Stage) - štádium rodičovstva teenagerov, vyžadujú, aby rodičia začali pozornejšie vnímat' sociálny svet diet'at’a mimo rodiny, usmerňovat' jeho mimoškolské aktivity, vytvárat' priestor pre hodnotné zážitky, nájst' si čas na vzájomné rozhovory, rozhodovat' sa o miere vol'nosti a samostatnosti, ktorú det’om poskytnú. Postupne redifinujú úroveň svojej rodičovskej kontroly a autority a budujú priestor pre autonómiu (aspoň čiastočnú) u dospievajúceho. Práve tu je pre rodiča nesmierne t’ažké, aj v súvislosti s témou, ktorú riešime, nájst' rovnováhu medzi ich požiadavkami a limitmi a slobodným rozhodovaním sa diet’at’a (Diener, M. L., 2020).

Podla správy EU Kids Online (2020), tak, ako deti dospievajú, najvýznamnejší vplyv na nich majú rodičia. Práve oni majú záujem na tom, aby deti z internetu vyt’ažili čo najviac pozitívneho a na druhej strane, aby 
zamedzili rizikám a nástrahám, ktoré prináša. Usmerňovanie využívania internetu det'mi rodičmi je označované ako „rodičovská mediácia“ (s. 69). Známe sú jej tri typy - „aktívna mediácia“" (,active mediation“), ktorá sa považuje za najžiadanejšiu, nakol'ko pri nej ide o rozhovory rodičov s det'mi o tom, ako internet využívajú, vymieňajú si vzájomné skúsenosti s internetom, diskutujú o tom, čo je na internete dobré a čo zlé. Táto mediácia je spojená s dobrými digitálnymi zručnost’ami a pripravuje deti adekvátne prijímat' internetové obsahy a reagovat' na potenciálne nepríjemné situácie pri jeho využívaní (s. 70). D̃alej je známy technický monitoring („technical monitoring"), ktorý vypovedá o tom, ako rodič vie napr. zistit', čo diet'a na internete robí (využívanie špecifických softwerov na získavanie informácií o online aktivitách). Napokon je to reštriktívna mediácia („restrictive mediation"), v ktorej jednoducho rodičia stanovujú pravidlá na prístup a čas, kedy deti môžu byt' na internete a aké aktivity môžu realizovat' online. Prirodzene, takto znižujú riziká, ktorým sú deti na internete vystavené, na strane druhej, deti získavajú menej digitálnych zručností a menje sú pripravené riešit' problematické situácie (s.71).

Vzhl’adom na národný kontext nášho výskumu za dôležité považujeme výskumy z domáceho prostredia, kde napr. M. Ceresnik a M. Ceresnikova (2019) zistili, že pri problémovom správaní dospievajúcich sa dá predpokladat' nízka úroveň stimulácie rodičmi (či iných zodpovedných osôb) a výchova $\mathrm{v}$ málo podnetnom prostredí. $\mathrm{Na}$ strane druhej, riziká problémového správania autori vidia aj $\mathrm{v}$ nadmernej stimulácii (prestimulovanie detského mozgu) napr. častým kontaktom s elektronickými modernými médiami (zvyšovanie aktivizačnej úrovne mozgu a vyhl'adávanie vzrušujúcich podnetov a pod.). Autori sledovali rôzne charakteristiky rodinného prostredia a rodičov, ktoré môžu byt' pričinou rizikového správania detí a dospievajúcich (smrt' v rodine, konflikty, ekonomická úroveň rodiny, výchovné štýly - nevhodnost' najmä autoritatívneho a benevolentného a pod.), resp. faktory protektívne, ktoré takéto správanie nenavodzujú (dobré rodinné vzt’ahy, otvorená komunikácia, neautoritatívna výchova, súlad v hodnotách a pod. (2019, s. 28-40). Analýzou rodinného prostredia vo vzt'ahu $\mathrm{k}$ rizikovému správaniu diet’ata sa výskumne venovali i autorky M. Verešová a J. Husvetyová (2005). V tomto kontexte prináša empirické výsledky i výskum uskutočnený R. Tomsikom a M. Veresovou (2019), v ktorom skúmali vzt’ah rôznych výchovných štýlov rodičov a vybraných oblastí rizikového správania adolescentov (užívanie návykových látok, šikanovanie a násilie, nevhodné stravovacie návyky, negatívny vzt’ah $\mathrm{k}$ škole a spolužiakom, negatívne vzt'ahy $\mathrm{v}$ rodine a rodinné rituály). Vo všetkých oblastiach sa ukázal ako najvhodnejší demokratický výchovný štýl rodičov, vzájomná rodinná komunikácia a priaznivé rodinné prostredie. Tieto pôsobia ako najdôležitejšie protektívne faktory rizikové správania detí a dospievajúcich.

\section{Sexting a miera rodičovskej kontroly $\mathrm{z}$ pohl'adu dospievajúcich}

Na základe viacerých zahraničných a domácich výskumných zistení sme v nasledujúcej časti formulovali vlastné výskumné ciele. V zahraničí je síce 
téma prediktorov sextingu výskumne riešená, ale $\mathrm{v}$ menšej miere ako iné otázky sextingu. Aj v našich podmienkach sú systematickejšie výskumy, ktoré by sa zaoberali touto problematikou, skôr sporadické. Našim zámerom bolo explorovat' tému $\mathrm{v}$ kontexte jedného $\mathrm{z}$ klúčových determinantov, ktoré sa podielajú na frekvencii a výskyte sextingu u dospievajúcich. Rodinné prostredie, kvalita vzájomných vztahov v rodine a štruktúra rodiny sú jednými z určujúcich faktorov, ktoré podmieňujú výskyt sextingu. Hlavným ciel'om štúdie bolo preskúmat' vzt'ah medzi frekvenciou odosielania self a peer-sextu a mierou rodičovskej kontroly z pohl'adu dospievajúcich.

\subsection{Metódy a metodika výskumu Výskumná vzorka}

Výskumu sa zúčastnilo 790 respondentov - (dospievajúcich vo veku 12 - 18 rokov). Z výskumnej vzorky bolo 376 chlapcov $(47,6 \%)$ a 414 dievčat $(52,4 \%)$. Náš výber vzorky mal charakter oblastného - stratifikovaného výberu.

\section{Metódy získavania dát, analýzy dát a metodika výskumu}

Výsledky boli získané administráciou upraveného dotazníka „Kyberšikana a sexting" (modifikovaný K. Hollou). Pri overení reliability použitého výskumného nástroja, sme sa opierali o štatistickú analýzu prostredníctvom využitia Cronbachovej alphy. Dotazník obsahoval vstupné, faktografické položky a otázky zamerané na skúmanie jednotlivých prediktorov sextingu u dospievajúcich. Reliabilita výskumného nástroja pre jednotlivé škály sa pohybovala v rozmedzí od vel’mi dobrá $(, 936)$ až diskutabilná $(, 681)$. Administrovaný dotazník sa zameriaval na viacero spolu súvisiacich problémov. S prihliadnutím na zameranie výskumnej štúdie uvádzame iba výsledky týkajúce sa vzt’ahov medzi frekvenciou odosielania sextu a mierou rodičovskej kontroly. Frekvenciu odosielania sextu hodnotili respondenti na škále 1 nikdy -2 raz -3 dvakrát -4 viac krát -5 každý deň. Posudzovanie výrokov týkajúcich sa miery rodičovskej kontroly hodnotili respondenti na škále: 1 súhlasím - 2 čiastočne súhlasím -3 neviem -4 skôr nesúhlasím - 5 nesúhlasím. Získané výsledky sme analyzovali prostredníctvom štatistického programu SPSS 21.0 for Windows. Ako testovacie kritérium bol použitý Spearmanov koeficient korelácie pri stanovení hladiny štatistickej významnosti 0,05 .

V rámci výskumu sme sledovali posudzovanie miery rodičovskej kontroly z pohl'adu dospievajúcich vo vzt’ahu:

- $\mathrm{k}$ self-sextingu, $\mathrm{t} \mathrm{j}$. online prezentovaniu vlastnej sexuality prostredníctvom posielania vlastných intímnych materiálov (zverejnenie/publikovanie vlastnej fotky na internete)

- k peer-sextingu, $\mathrm{t}$ j. posielaniu erotických a sexuálnych materiálov svojich kamarátov a spolužiakov, vrátane vyžiadania si intímnych materiálov pre vlastnú potrebu (odoslanie nahej fotografie spolužiaka, odoslanie nahej fotografie inej osoby, odoslanie žiadosti o zaslanie fotografie, preposlanie nahej fotografie osoby, ktorú dospievajúci pozná).

Oblast' posudzovania miery rodičovskej kontroly dospievajúcimi sýtili nasledovné výroky: $s$ rodičmi sa rozprávame o online nástrahách a rizikách, 
rodičia kontrolujú moju činnost' na webe, vždy, ked' sa cítim online ohrozený poviem to rodičom, rodičov moje online aktivity a online vztahy nezaujímajú, rodičia využivajú rôzne formy kontroly mojej činnosti na webe.

\subsection{Výsledky}

Pri testovaní jednotlivých vzt’ahov sme štatisticky významné výsledky dosiahli pri posudzovaní výrokov týkajúcich sa intenzity rozhovorov $\mathrm{s}$ rodičmi: $s$ rodičmi sa rozprávame o online nástrahách a rizikách, vždy, ked' sa cítim online ohrozený, poviem to rodičom a zhodnotenia miery kontroly rodičmi (rodičia kontrolujú moju činnost' na nete). Štatisticky významné vzt’ahy, ktoré uvádzame v nasledujúcej časti, sme zaznamenali iba v oblasti peer-sextingu.

Na základe dosiahnutých výsledkov je možné uviest', že existuje súvis medzi frekvenciou odoslania peer-sextingu a intenzitou komunikácie $\mathrm{s}$ rodičmi (rodičovskej mediácie) o online nástrahách a rizikách. Dospievajúci, ktorí označovali, že sa nerozprávajú s rodičmi o online nástrahách a rizikách, častejšie odošlú nahú fotografiu spolužiaka, inej osoby, častejšie odošlú žiadost' o zaslanie nahej fotografie, alebo d’alej prepošlú nahú fotografiu osoby, ktorú poznajú (tab. č. 1). Podobné vysoko signifikantné výsledky sme dosiahli aj pri posudzovaní výroku: „vždy, ked’ sa cítim online ohrozený, poviem to rodičom ". Č́́m menej sa respondenti stotožňujú s výrokom, tým sa rizikovejšie online správajú (tab. č. 1).

Tab. č. 1. Vzt’ah medzi frekvenciou odoslania peer-sextingu a intenzitou komunikácie s rodičmi o online nástrahách a rizikách

\begin{tabular}{|c|r|r|r|r|r|}
\hline & $\begin{array}{c}\text { odoslanie nahej } \\
\text { foto spolužiaka }\end{array}$ & $\begin{array}{c}\text { odoslanie nahej } \\
\text { foto inej osoby }\end{array}$ & $\begin{array}{c}\text { odoslanie žiadosti } \\
\text { o zaslanie fotky }\end{array}$ & $\begin{array}{c}\text { preposlanie } \\
\text { nahej fotky } \\
\text { osoby, ktorú } \\
\text { poznáś }\end{array}$ \\
\hline $\begin{array}{c}\text { s rodičmi } \\
\text { rozprávame } \\
\text { o online } \\
\text { nástrahách }\end{array}$ & $\rho$ &, $116^{* * *}$ &, $165^{* * *}$ &, $135^{* * *}$ &, $117^{* *}$ \\
\hline $\begin{array}{c}\text { ked' sa cítim } \\
\text { ohrozený, } \\
\text { poviem to } \\
\text { rodičom }\end{array}$ & $\rho$ &, $127^{* *}$ &, $154^{* *}$ &, $139^{* * *}$ &, $123^{* * *}$ \\
\hline & $\mathrm{N}$ & 790 & 790 & & \\
\hline
\end{tabular}

Vysvetlivky: $\rho$ - Spearmanov koeficient korelácie, sig. - dosiahnutá signifikancia $(>0,05$ nesignifikantná; $\leq 0,05$ signifikantná $*$; 0,01 vysoko signifikantná ${ }^{* *} ; \leq 0,001$ velmi vysoko signifikantná $* * *)$

Frekvenciu odosielania sextu hodnotili respondenti na škále 1 nikdy - 2 raz - 3 dvakrát - 4 viac krát - 5 každý deň. Posudzovanie výrokov týkajúcich sa miery rodičovskej kontroly a intenzity komunikácie s rodičmi hodnotili respondenti na škále: 1 súhlasím - 2 čiastočne súhlasím - 3 neviem - 4 skôr nesúhlasím - 5 nesúhlasím.

Na základe analýzy výsledkov uvádzame tiež vysoko signifikantný vzt’ah medzi frekvenciou odoslania peer-sextingu a mierou rodičovskej kontroly v oblasti online správania sa dospievajúcich. 
Dospievajúci, ktorí označovali, že rodičia nekontrolujú ich činnost' na webe, častejšie priznávali odoslanie nahej fotografie spolužiaka a inej osoby. Zároveň tiež častejšie priznávali odoslanie žiadosti o zaslanie nahej fotografie, alebo d’alej preposlali nahú fotografiu osoby, ktorú poznajú (tab. č. 2 ).

Tab. č. 2. Vztah medzi frekvenciou odoslania peer-sextingu a mierou rodičovskej kontroly

\begin{tabular}{|c|r|r|r|r|r|}
\hline & & $\begin{array}{c}\text { odoslanie } \\
\text { nahej foto } \\
\text { spolužiaka }\end{array}$ & $\begin{array}{c}\text { odoslanie nahej } \\
\text { foto inej osoby }\end{array}$ & $\begin{array}{c}\text { odoslanie } \\
\text { žiadosti } \\
\text { o zaslanie fotky }\end{array}$ & $\begin{array}{c}\text { preposlanie nahej } \\
\text { fotky osoby, ktorú } \\
\text { poznáśs }\end{array}$ \\
\hline $\begin{array}{c}\text { rodičia mi } \\
\text { kontrolujú } \\
\text { činnost' } \\
\text { na webe }\end{array}$ & $\rho$ &, $123^{* *}$ &, 098 &, 064 &, 044 \\
\hline & $\mathrm{N}$ & 790 & 790 & & 790 \\
\hline
\end{tabular}

Vysvetlivky: $\rho$ - Spearmanov koeficient korelácie, sig. - dosiahnutá signifikancia (> 0,05 nesignifikantná; $\leq 0,05$ signifikantná $* ; \leq 0,01$ vysoko signifikantná $* * ; \leq 0,001$ velmi vysoko signifikantná $\left.{ }^{* * *}\right)$

Frekvenciu odosielania sextu hodnotili respondenti na škále 1 nikdy - 2 raz - 3 dvakrát - 4 viac krát - 5 každý deň. Posudzovanie výrokov týkajúcich sa miery rodičovskej kontroly a intenzity komunikácie s rodičmi hodnotili respondenti na škále: 1 súhlasím - 2 čiastočne súhlasím - 3 neviem - 4 skôr nesúhlasím - 5 nesúhlasím.

\subsection{Diskusia}

Klúčovým zistením realizovaného výskumu je zistenie, že dospievajúci, ktorí označovali, že sa nerozprávajú s rodičmi o online nástrahách a rizikách a hodnotili, že rodičia nekontrolujú ich činnost' na webe, častejšie priznávajú peer-sexting. Posielanie erotických a sexuálnych materiálov svojich kamarátov a spolužiakov, vrátane vyžiadania si intímnych materiálov pre vlastnú potrebu, je tak závislé od zástoja rodičov v online aktivitách ich dospievajúcich detí.

Viaceré výskumy potvrdzujú, že riziká sextingu sa znižujú, ak medzi det'mi a ich rodičmi existujú úprimné a láskavé vztahy, rodičia aplikujú žiaduce výchovné metódy a otvorene (primerane veku dietata) diskutujú aj o témach intímneho života. Uvedené výsledky tak naznačujú aktuálnu potrebu systematického riešenia. Vytvorenie platformy a priebežná realizácia poradenstva rodičom $\mathrm{k}$ online rizikovému správaniu sa dospievajúcich by mohli byt' jednými z riešení nastolených problémov. $\mathrm{V}$ tomto kontexte je možné uviest' prehl'adovú štúdiu autorky N. Döring (2014), ktorá si ako jeden z ciel'ov stanovila zmapovat' súčasný prehl'ad výskumov a oficiálnych svetových preventívnych programov zameraných na prevenciu sextingu a jeho nástrah a rizík pre adolescentov. Autorka na základe analýzy vybraných preventívnych programov zdôrazňuje neustále sa zvyšujúcu potrebu vzdelávania mládeže, rodičov, učitel'ov a detí (viac pozri: Doring, N., 2014). 
Nami dosiahnuté výsledky podporujú aj zistenia iných autorov. S. E. Baumgartner et al. (2014), zistili, že mladí l'udia s vyššou frekvenciou online sexuálneho správania pochádzajú skôr $\mathrm{z}$ menej harmonických rodín. Dospievajúci s nižšou kvalitou vzájomných vzt’ahov v rodine (najmä komplikované a zlé vzt’ahy) štatisticky významne častejšie podliehali selfa peer-sextingu. Uvedené autori vysvetl'ujú najmä nižšou mierou kontroly, dôvery a intenzity kontaktu v rodinách s komplikovanými, až zlými vzt’ahmi. Tieto zistenia podporujú aj iné štúdie. Spomenút' možno napr. švédsku štúdiu L. S. Jonsson (2015), kde bola zistená súvislost' medzi rizikovým online sexuálnym správaním adolescentov a zlým vzt’ahom s rodičmi. V štúdii autorka dokonca uvádza koreláciu medzi zasielaním vlastnej nahej fotografie a autoritatívnou výchovou. Aj autori M. Temple Smith - S. Moore,- D. Rosenthal (2015), uvádzajú, že je to práve výchovný štýl rodiny, ktorý výraznou mierou ovplyvňuje úroveň online sexuálneho správania sa dospievajúcich. Autori zdôrazňujú význam kvality rodinných vzt'ahov a celkovej podpory dospievajúceho v tejto oblasti.

Na zamyslenie stojí aj praktizovanie tzv. „sharenting“. Ide o výraz, ktorý na Slovensku nemá ekvivalent (vznikol z kombinácie dvoch anglických slov: „sharing“- zdiel'anie, podelenie sa, a slova „parenting“, rodičovstva). Slovo sa používa na situácie, ked' rodičia prezentujú v online priestore informácie o svojich det'och, rozosielajú ich fografie, videá, komentujú ich úspechy, problémy a podobne. Zdiel'anie radosti z detí je určite prirodzenou súčastou rodičovstva a rodičia bežne takéto aktivity robia (a to od prvého momentu po narodení diet'atka). Ako však upozorňujú autori správy EU Kids Online 2020, i tu môžu nastat' situácie, ktoré v budúcnosti môžu diet'a negatívne ovplyvnit'. Rodičia by si mali uvedomit', že i na prvý pohl'ad nevinné fotky, resp. videá (napr. nahých hrajúcich sa, či kúpajúcich sa detí) môžu byt' zneužité (aj po uplynutí istého času po ich zverejnení, rozoslaní priatel'om). Čo sa týka starších detí, rozosielanie vizuomateriálov o nich by v každom prípade malo byt' diet'at'om najskôr odsúhlasené (Práva diet'at’a na súkromie). „Sharenting“ má teda rovnako pozitívnu, ale aj negatívnu stránku, čo si rodičia musia uvedomit' v záujme dobra svojho diet’at’a (s. 125). Okrem toho, podl'a nás, odsúhlasenie odoslania napr. fotografie diet'at'a (dospievajúceho) rodičmi príbuzným, či priatel'om samotným diet’at'om má v zmysle nami sledovanej problematiky i významný edukačný efekt. Rodič tu pre diet'a slúži ako vzor pri dodržiavaní etických pravidiel online komunikácie, netikety (angl. netiquette).

\section{Záver}

Riešená téma má prirodzene širší rozmer ako sme načrtli. Realizovanie selfa peer-sextingu môže byt' tiež vnímané ako súčast' prirodzeného procesu dospievania v súčasnej „online“ dobe. O to dôležitejšie preto vystupuje potreba otvorenej komunikácie rodičov s dospievajúcimi det'mi aj o témach intímneho života, pedagogizácia rodičov a celého prostredia domácnosti. Stabilné rodinné prostredie, v ktorom prevládajú dobré vzájomné vzt’ahy, je tak významným protektívnym faktorom pred vyššou frekvenciou odosielania self a peer-sextu a angažovania sa dospievajúceho v tejto oblasti virtuálneho sveta. 


\section{Pod'akovanie}

Príspevok je súčast'ou riešenia výskumnej úlohy VEGA č. 1/0100/18 „Selfsexting a peer-sexting a možnosti pedagogického ovplyvňovania“.

\section{Bibliographical references}

ANASTASSIOU, A. 2017. Sexting and young people: A review of the qualitative literature. The Qualitative Report, vol. 22, n.8 pp.2231-2239.

BERNS, R. M. 2012. Child, family, school, community: Socialization and support. Wadsworth, Cengage Learning 2010. U.S. edition. ISBN 13: 978-0495-80485-7.

BUREN, J. 2018. Sexting among adolescents. Gothenburg, Sweden, Avhandling/Göteborgs universitet.

BAUMGARTNER, S. E. - SUMTER, S. R. - PETER, J. VALKENBURG, P. M. - LIVINGSTONE, S. 2014. Does country context matter? Investigating the predictors of teen sexting across Europe. Computers in Human Behavior, vol. 34, pp. 157-164.

BARRENSE-DIAS, Y. - BERCHTOLD, A. - SURIS, J. C. - AKRE, C. 2017. Sexting and the definition issue. Journal of Adolescent Health, vol. 61, n. 5, pp. 544-554.

BRONFENBRENNER, U. 1979. The ecology of human development. Harvard university press.

COOPER, A. - MCLOUGHLIN, I. P. - CAMPBELL, K. M. 2000. Sexuality in Cyberspace: Update for the 21st century. CyberPsychology \& Behavior, vol. 3, n.4, pp. 521-536.

COOPER, A. - GRIFFIN-SHELLEY, E. 2002. Introduction. The Internet: The Next Sexual Revolution. In Cooper, Al (ed.) Sex and the Internet: A guidebook for clinicians, Brunner-Routledge, New York, ISBN 1-58391-3556.

CERESNIK, M. - CERESNIKOVA, M. 2019. Vnimanie vychovnych stylov a prejavy rizikoveho spravania dospievajucich $\mathrm{v}$ systeme nizsieho sekundarneho vzdelavania. Diskuze v psychologii, n. 1, pp. 28-40

DORING, N. 2014. Consensual Sexting among Adolescents: Risk Prevention Through Abstinence Education or Safer Sexting? Cyberpsychology: Journal of Psychosocial Research on Cyberspace, 2014, vol. 8, n. 1.

DIENER, M. L. 2020. The Developing Parent. In: R. BISWAS-DIENER E. DIENER (Eds). Noba textbook series: Psychology. Champaign, IL: DEF publishers.

GRIFFITHS, M. 2017. Sex and the Internet. Another Brief Look at the Psychology of Cybersex. Psychology Today.

HALACHOVA, M. - ROVENSKA, D. 2017. Virtualne a realne prostredie dospievajuceho. Kosice: Univerzita Pavla Jozefa Safarika, ISBN 978-808152-532-2

HOLLA, K. 2017. Detekcia kyberagresie-kybersikanovania a sextingu. Nitra: PF UKF. ISBN 978-80-558-1205-2.

HOLLA, K. 2017. Prevencia kyberagresie a kybersikanovania. Nitra: PF UKF, ISBN 978-80-558-1210-6.

HOLLA, K. Vyskyt sextingu u mladych ludi na Slovensku, Iuventa, online. 
HERTLEIN, K. M. - STEVENSON, A. 2010. The seven "As" contributing to Internet-related intimacy problems: A literature review. Cyberpsychology: Journal of Psychosocial Research on Cyberspace, vol. 4, n.1.

JONSSON, L. S. 2015. Online Sexual Behaviours Among Swedish Youth. Characteristics, Associations and Consequences, Linköping, Sweden, ISBN 978-91-7519-128-7.

JESSOR, R. 1991. Risk Behaviour in Adolescence: A Psychosocial Framework for Understanding and Action. Journal of Adolescent Health, vol. 12 , n. 8, pp. 597-605.

KOPECKY, K. 2015. Sexting among slovak pubescents and adolescent children. Procedia-Social and Behavioral Sciences, vol. 203, pp. 244-250

KURINCOVA, V. - TURZAK, T. - ZELENA, H. 2018. Spolupraca rodiny a skoly $\mathrm{v}$ kontexte prevencie elektronickeho sikanovania. In: Perspektivy rozvoja pedagogiky a andragogiky $\mathrm{v}$ Slovenskej republike a $\mathrm{v}$ krajinach strednej Europy. Bratislava: UK, ISBN 978-80-23-4706-8, pp. 97-105.

LEIBLUM, S. - DORING, N. 2002. Internet Sexuality: Known Risks and Fresh Chances for Women. In Cooper, Al (ed) Sex and the Internet: A Guidebook for Clinicians, Brunner-Routledge, New York, pp. 19-45. ISBN 1-58391-355-6,

MARTINEZ-PRATHER, K. - VANDIVER, D. M. 2014. Sexting among Teenagers in the United States: A Retrospective Analysis of Identifying Motivating Factors, Potential Targets, and the Role of a Capable Guardian. International Journal of Cyber Criminology, vol. 8, n. 1.

NORMAN, J. M., 2017. Implications of parenting behaviour and adolescent attachment for understanding adolescent sexting. Electronic Theses and Dissertations.

SORBRING, E. - SKOOG, T. - BOHLIN, M. 2014. Adolescent Girls' and Boys' Well-being in Relation to Online and Offline Sexual and Romantic Activity. Cyberpsychology: Journal of Psychosocial research on cyberspace, vol. 8, n.1.

TEMPLE-SMITH, M. - MOORE, S. - ROSENTHAL, D. 2015. Sexuality in Adolescence: The Digital Generation. Routledge.

TURZAK, T. - KURINCOVA, V. - HOLLA, K. - ZELENA, H. 2020. Sexting and family environment of children and adolescents. In. Ad Alta : Journal of Interdisciplinary Research, 2020, vol. 10, n. 2, ISSN 1804-7890, (In press).

VERESOVA, M. - TOMSIK, R. 2019. Rizikove spravanie dospievajucich a vychovne styly v rodine. Nitra: UKF. ISBN 978-80-558-1404-9.

SMAHEL, D. et all. 2020. EU Kids Online 2020: Survey results from 19 countries. EU Kids, Online.

SUBRAHMANYAM, K. - GREENFIELD, P. M. - TYNES, B. 2004. Constructing sexuality and identity in an online teen chat room. Journal of applied developmental psychology, vol.25, n.6, pp. 651-666.

SUBRAHMANYAM, K. - GREENFIELD, P. M. 2008. Online communication and adolescent relationships. The future of children, vol.18, n. 1, pp.119-146.

WALKER, S. J. 2012. Sexting and young people: A qualitative study. 
WIGHT, D. - WILLIAMSON, L. - HENDERSON, M. 2006. Parental Influences on Young People's Sexual Behaviour: A Longitudinal Analysis. Journal of adolescence, vol. 29, n. 4, pp. 473-494.

PaedDr. Tomáš Turzák, PhD.

prof. PhDr.Viera Kurincová, CSc.

doc. PaedDr. Katarína Hollá, PhD.

Department of pedagogy

Faculty of education

Constantine the Philosopher University in Nitra

Dražovská cesta 4, Nitra

Slovak Republic

tturzak@ukf.sk

vkurincova@ukf.sk

kholla@ukf.sk 